\title{
PENGUJIAN KUAT TEKAN BETON TERHADAP PENGGUNAAN CANGKANG KEMIRI PADA BETON RAMAH LINGKUNGAN
}

\author{
Oleh: \\ Johan Oberlyn Simanjuntak ${ }^{1)}$ \\ Tiurma Elita Saragi ${ }^{2)}$ \\ Nurvita Insani Simanjuntak ${ }^{3)}$ \\ Imesari Hulu ${ }^{4}$ \\ Universitas HKBP Nommensen, Medan 1,2,3,4) \\ E-mail : \\ oberlyn.simanjuntak@yahoo.co.id $^{1)}$ \\ saragih_27@yahoo.com ${ }^{2)}$ \\ nurvitainsani@gmail.com ${ }^{3}$ \\ imesari.hulu@student.uhn.ac.id ${ }^{4)}$
}

\begin{abstract}
One of the factors of economic growth is the development of infrastructure to encourage the creation of various activities. Concrete becomes an important part in the process of infrastructure development. For the concrete mixture, gravel is the most important part for concrete constituents. The limitation of gravel in nature led to the creation of various studies to replacement solutions for the use of gracel in concrete mixtures. Candlenut shell is one of the waste is not getting attention in its uses. Department of Plantation North Sumatera Province recorded the candlenut production in North Sumatera in 2019 reached 13,529.40 tons. The study aims for replace some of the gravel in the concrete mixture by using a candle nut shell. The variety of concrete mixture with candle nut is 10\%, 20\% and 30\%. Testing was conducted on concrete ages 7 days, 14 days, 21 days and 28 days aimed at finding the difference between normal concrete compressive strength without additional candlenut shells and concrete with additional candlenut shells. The result shows that there was a decrease in the values of concrete compressive strength for each group of test objects. The decrease is due to the candlenut shell having higher and water absorption compared to gravel.
\end{abstract}

Keywords : Concrete Compressive Strength, Candlenut Shells

\section{ABSTRAK}

Salah satu faktor pertumbuhan ekonomi adalah dengan pembangunan infrastruktur yang memadai untuk mendorong terciptanya berbagai kegiatan.Beton menjadi satu bagian penting dalam proses pembangunan infrastruktur. Dalam campuran pembentuk beton, kerikil ialah bagian utama penyusun beton.Keterbatasan kerikil di alam mendorong terciptanya berbagai penelitian untuk memberikan solusi pengganti penggunaan kerikil dalam campuran adukan beton.Cangkang kemiri ialah salah satu dari limbah buangan yang kurang mendapat perhatian dalam pemanfaatannya.Dinas Perkebunan Sumatera Utara mencatatkan produksi kemiri di Sumatera Utara Tahun 2019 mencapai 13.529,40 ton.Penelitian ini bertujuan untuk menggantikan sebagian kerikil pada campuran beton dengan menggunakan cangkang kemiri. Variasi campuran adukan beton dengan cangkang kemiri adalah 10\%,20\% dan 30\%. Pengujian dilakukan pada beton dengan umur 7 hari, 14 hari, 21 hari dan 28 hari yang bertujuan untuk menemukan perbedaan antara kuat tekan beton normal tanpa tambahan cangkang kemiri dan beton dengan tambahan cangkang kemiri.Dari hasil pengujian yang dilakukan, didapatkan bahwa terjadi penurunan nilai kuat tekan beton pada benda uji beton dengan tambahan cangkang kemiri.Penurunan tersebut diakibatkan karena cangkang kemiri memiliki nilai penyerapan air yang lebih tinggi dibandingkan dengan kerikil.

\section{Kata Kunci : kuat tekan beton, cangkang kemiri}




\section{PENDAHULUAN}

Konstruksi Dalam Angka Tahun 2019 yang dikeluarkan oleh Badan Pusat Statistik menjabarkan bahwa pada Triwulan III/2019 tercatat besarnya persentase sektor konstruksi terhadap PDB (Produk Domestik Bruto) Indonesia adalah sebesar $10,60 \%$. Hal ini menjelaskan bahwa selain sektor industri pengolahan, sektor pertanian maupun sektor kehutanan, sektor konstruksi juga memegang peranan dalam kemajuan perekonomian Indonesia. Peranan sektor konstruksi ditunjukkan dengan pertambahan jumlah infrastruktur baik perumahan/ apartemen, kantor layanan publik, rumah sakit, pusat perbelanjaan/mall, rumah ibadah, jalan raya, bendungan dan bangunan lainnya yang menunjang berbagai kegiatan di Indonesia.

Peningkatan bahan pembentuk beton akan meningkat seiring juga peningkatan pembangunan infrastruktur. Beton merupakan material penting dalam pekerjaan konstruksi. Dalam proses pembentukan beton, komponen utamanya ialah agregat, semen portland dan air. Pada agregat kasar digunakan batu pecah ataupun kerikil sedangkan pada agregat halus pada umumnya digunakan pasir. Seperti halnya pasir, kerikil merupakan material yang didapatkan dari alam yang memiliki keterbatasan sehingga lambatlaun ketersediannya akan berkurang bahkan akan habis.

Menurut Johan, dll (2020) dalam proses pembuatan beton, semen dan bahan lainnya sebagai penyusun utama dibakar hingga $\pm 800^{\circ} \mathrm{C}-1000^{\circ} \mathrm{C}$. Dalam proses pembakaran tersebut melepaskan $\mathrm{CO}_{2}$ dalam jumlah besar yang pada akhirnya dapat menambah emisi gas rumah kaca. Selain dari proses pembuatan beton, salah satu penyebab kerusakan lingkungan lainnya adalah limbah. Limbah dapat dimanfaatkan sebagai bahan campuran beton sehingga menghasilkan beton yang ramah lingkungan.Selain dapat mengurangi penggunaan kerikil/batu pecah sebagai bahan pencampur adukan beton, penggunaan limbah juga sekaligus dapat mengurangi limbah yang ada. Pusat Standarisasi Lingkungan dan Kehutanan (2021), menjelaskan bahwa dalam pembuatan teknologi ramah lingkungan dalam penerapannya menggunakan bahan baku yang dapat membantu mengurangi bahkan dapat mencegah terjadinya pencemaran.

Dinas Perkebunan Sumatera Utara mencatatkan produksi kemiri di Sumatera Utara Tahun 2019 mencapai 13.529,40 ton.Dengan demikian perlu dilakukan suatu pengujian dengan menggunakan cangkang kemiri dikarenakan pada umumnya cangkang kemiri hanya menjadi limbah buangan yang kurang diperhatikan pemanfaatannya. Dengan demikian, pengujian ini dilakukan dengan cara menambahkan cangkang kemiri pada campuran adukan beton sebagai substitusi/pengganti sebagian kerikil sehingga

diharapkan mampu menghasilkan beton dengan kualitas baik dan ramah lingkungan. Tujuan yang ingin dicapai dalam pengujian ini adalah untuk mengetahui berapa besar nilai kuat tekan beton antara beton tanpa tambahan cangkang kemiri dan beton dengan campuran kemiri variasi $10 \%, 20 \%$ dan $30 \%$.

\section{TINJAUAN PUSTAKA \\ Beton}

Menurut SK SNI 03-2847-2002, beton ialah campuran semen portland/semen hidrolik jenis lain dengan tambahan agregat, air dan/atau tanpa bahan tambah lainnya yang akan membentuk pasta padat.

Persyaratan beton yang harus dipenuhi dalam perencanaannya antara lain :

1. Dalam perencanaan campuran beton, perhitungan didasarkan atas data sifat-sifat bahan yang akan digunakan pada produksi beton

2. Susunan campuran beton yang didapatkan dari perencanaan dilakukan melalui percobaan pencampuran yang menghasilkan bahwa perencanaan memenuhi syarat kekuatan beton

Menurut Nugraha (2007) keunggulan dan kelemahan beton dijabarkan sebagai berikut : 
1. Keunggulan beton

a. Ketersediaan (availability) unsur penyusun beton dapat diperoleh dari lokasi setempat sehingga mudah dalam proses pengangkutannya

b. Beton bersifat menyatu secara kaku yang disebut monolit

c. Beton dapat dicetak sesuai dengan kebutuhan, baik dari segi bentuk dan ukuran

d. Proses produksi beton dapat disesuaikan dengan kondisi setempat

e. Proses pemeliharaan yang relatif mudah

2. Kelemahan beton

a. Beton memiliki massa jenis yang besar yaitu $2400 \mathrm{~kg} / \mathrm{m}^{3}$

b. Beton memiliki nilai kuat tarik yang rendah

c. Kualitas beton sangat bergantung pada proses pengerjaannya di lapangan meskipun memiliki bahan campuran yang sama

d. Beton yang sudah mengeras sulit untuk di daur ulang dan dipindahkan

\section{Material Penyusun Beton \\ Semen Portland}

"Semen Portland merupakan semen hidrolis yang dihasilkan dengan cara menggiling terak semen portland terutama yang terdiri atas kalsium silikat yang bersifat hidrolis dan digiling bersama-sama dengan bahan tambahan berupa satu atau lebih bentuk kristal senyawa kalsium sulfat dan boleh ditambah dengan bahan tambahan lain" (SNI 15-2049-2004). Menurut Lincolen (2017), semen hidrolis ialah semen yang bisa mengeras jika bereaksi dengan air dan menghasilkan senyawa padat. Irreversible dalam pengertian hanya dapat terjadi satu kali dan tidak dapat lagi kembali ke kondisi semula atau stabil dalam air setelah mengeras merupakan reaksi semen dengan air.

Menurut BPSDM Kemen PUPR (2017), secara garis beras ada empat (4) senyawa kimia utama yang menyusun semen portland yaitu Trikalsium Silikat $\left(3 \mathrm{CaO} . \mathrm{SiO}_{2}\right)$ disingkat menjadi $\mathrm{C}_{3} \mathrm{~S}$, Dikalsium Silikat $\left(2 \mathrm{CaO} . \mathrm{SiO}_{2}\right)$ disingkat menjadi $\mathrm{C}_{2} \mathrm{~S}$, Tektrakalsium Aluminoferrit $\left(4 \mathrm{CaO} \cdot \mathrm{Al}_{2} \mathrm{O}_{3} \cdot \mathrm{Fe}_{2} \mathrm{O}_{3}\right)$ disingkat menjadi $\mathrm{C}_{4} \mathrm{AF}$. Senyawa-senyawa kimia tersebut akan berubah menjadi kristal-kristal yang saling mengikat ketika menjadi klinker. Komposisi antara $\mathrm{C}_{3} \mathrm{~S}$ dan $\mathrm{C}_{2} \mathrm{~S}$ mengambil bagian $70 \%$ $80 \%$ dari total berat semen dan merupakan bagian paling dominan terhadap sifat semen. Sifat-sifat fisik semen meliputi :

1. Kehalusan butir

Kehalusan butir semen berpengaruh terhadap laju proses hidrasi dan perkembangan kekuatan beton

2. Konsistensi

Konsistensi mempengaruhi semen portlandpada saat proses pencampuran awal yaitu ketika terjadi pengikatan sampai saat beton mengeras. Konsistensi semen tergantung pada rasio antara air dan semen serta faktor-faktor lain seperti kehalusan semen dan kecepatan hidrasi.

3. Waktu pengikatan

Untuk mengontrol pekerjaan beton, hal yang terpenting adalah waktu pengikat yaitu waktu yang digunakan semen untuk proses mengeras yang dihitung mulai dari semen berekasi dengan air sampai menjadi pasta semen yang kaku dan dapat menahan tekanan.

4. Perubahan volume (soundness)

Pengembangan volume pada pasta semen dapat berakibat retak, gangguan dan disintegrasi pada beton

5. Kekuatan

Pengujian kekuatan semen didasarkan pada kekuatan campuran mortar. Jenis pengujian kekuatan yaitu uji kuat tekan (compression) dan uji kuat tarik lentur (flexure)

\section{Agregat Kasar dan Agregat Halus}

Menurut PBI (1971) agregat ialah butiranbutiran mineral yang dicampur dengan semen portland beserta air untuk menghasilkan beton.

Agregat halus adalah mineral alami yang berguna untuk mengisi dalam campuran beton yang berukuran butir kurang dari 5 $\mathrm{mm}$ atau lolos saringan no.4 dan tertahan saringan no.200.agregat halus merupakan hasil disintegrasi alami yang berasal dari batuan alam atau pasir buatan yang didapatkan dari alat pemecah batu.

Fungsi agregat dalam campuran beton ialah sebagai bahan pengisi. Agregat memiliki proporsi yang besar dalam campuran beton 
yaitu antara $60 \%$ - 70\% dari total berat campuran beton.

Sifat agregat yang perlu diperhatikan dalam campuran beton (BPSDM Kemen PUPR, 2017) adalah :

1. Volume udara

Pada proses pembuatan beton, volume udara pada agregat akan memberikan pengaruh terutama setelah campuran berbentuk pasta semen

2. Kepadatan volume

Berat isi campuran adukan beton akan dipengaruhi oleh kepadatan volume agregat

3. Berat jenis agregat

Berat campuran beton juga akan dipengaruhi berat jenis agregat dalam proporsi campuran adukan

4. Penyerapan agregat

Penyerapan agregat akan mempengaruh berat jenis

5. Kadar air permukaan agregat

Penggunaan air saat pencampuran agregat kasar juga mempengaruhi kadar air permukaan agregat

\section{Air}

Pasta semen pengikat terjadi ketika dalam proses pembuatan beton, air berekasi terhadap semen. Kelebihan jumlah air yang digunakan dalam campuran beton juga serta merta akan mempengaruhi kuat tekan beton dikarenakan air yang terlalu banyak akan menyebabkan penurunan kekuatan tekan beton. Selain turunnya nilai kuat tekan beton, kelebihan jumlah air akan mengakibatkan air dan semen akan bergerak bersamaan naik ke atas permukaan adukan beton yang disebut dengan bleeding.

Tujuan utama penggunaan air pada pembuatan beton adalah :

1. Untuk proses hidrasi

Hidrasi ialah reaksi yang terjadi antara semen dan air yang menghasilkan campuran keras

2. Untuk curing beton

Perawatan (curing) beton dilakukan untuk mengontrol proses pengerasan sempurna beton

Berdasarkan SK SNI 03-2847-2002, syarat air yang dapat digunakan dalam campuran adukan beton antara lain :
1. air yang akan digunakan bebas dari bahan yang dapat merusak beton ataupun tulangan diantarnya, minyak, asam, alkali, garam

2. Air yang terkadung dalam agregat yang akan digunakan juga harus bebas dari kandungan ion klorida dalam jumlah yang membahayakan

3. Air yang akan digunakan ialah air yang dapat diminum kecuali air yang tidak dapat diminum telah lebih dahulu digunakan pada percobaan lainnya dengan menggunakan beton umur 7 hari dan 28 hari. Pada beton yang menggunakan air yang tidak dapat diminum harus menunjukkan nilai kuat tekan beton $\pm 90 \%$ dari kuat tekan beton dengan campuran air yang dapat diminum

\section{Proporsi Campuran Beton}

Menurut BPSDM Kemen PUPR (2017), beberapa faktor yang menentukan proporsi campuran adukan beton antara lain :

1. Faktor air semen (fas),

Faktor air semen (fas) berarti bahwa pada kondisi nilai fas tinggi, maka muku kuat tekan tekan beton akan menurun atau rendah

2. Tipe semen

3. Durability (keawetan)

Keawetan beton akan dipengaruhi oleh kadar air semen, fakor air semen maksimum dan nilai kekuatan minimum

4. Workabilitas dan jumlah air

5. Kemudahan dalam pengerjaan beton akan digambarkan dari konsistensi campuran adukan yang dinyatakan dengan nilai slump. Untuk memeriksa camuran adukan, maka digunakan batas nilai slump yang dijabarkan pada Tabel 1.

Tabel 1. Batas-batas nilai slump

\begin{tabular}{|l|c|}
\hline \multicolumn{1}{|c|}{ Jenis pekerjaan } & Slump \\
\hline $\begin{array}{l}\text { Dindind pelat pondasi dan } \\
\text { pondasi telapak bertulang }\end{array}$ & $5,0-12,5$ \\
\hline $\begin{array}{l}\text { Konstruksi bawah tanah, } \\
\text { kaison dan pondasi telapak } \\
\text { tidak bertulang }\end{array}$ & $2,5-9,0$ \\
\hline $\begin{array}{l}\text { balok, kolom, dinding dan } \\
\text { pelat }\end{array}$ & $7,5-15,0$ \\
\hline Perkerasan jalan & $5,0-7,5$ \\
\hline Pembetonan masal & $2,5-7,5$ \\
\hline
\end{tabular}


Sumber : Pedoman Konstruksi dan Bangunan (2005)

6. Pemilihan agregat

Dalam menentukan proporsi campuran adukan, penggunaan agregat disyaratkan dengan menggunakan ukuran maksimum sehingga dapat disesuaikan dengan biaya, ketersediaan agregat dan jarak tulangan terkecil. Agregat kasar dipilih kurang dari $3 / 4$ jarak bersih minimum antara baja tulangan dengan acuan atau antara celah-celah lain dimana beton akan dicorkan.

7. Kadar semen

Penentuan penggunaan kadar semen diperoleh dari hasil perancangan dan kemudian dibandingkan dengan syarat kadar semen minimum. Retak beton akibat tingginya hidrasi menjadi tujuan utama penentuan kadar semen selain pertimbangkan durabilitas

\section{Kuat Tekan Beton}

Menurut SNI 03-1974-1990, kuat tekan beton adalah besarnya beban per satuan luas penampang, yang menyebabkan benda uji beton akan hancur bila diberikan beban dengan gaya tekan tertentu, yang dihasilkan mesin tekan beton.

Beberapa faktor yang akan mempengaruhi kuat tekan beton (Kardiyono Tjokrodimulyo, 1972) di antaranya adalah :

1. Pengaruh mutu semen

2. Pengaruh perbandingan campuran beton

3. Pengaruh air dalam pembuatan campuran

4. Pengaruh umur beton

5. Pengaruh waktu pencampuran

6. Pengaruh perawatan

7. Pengaruh bahan pencampur tambahan Pada umumnya kuat tekan beton dapat dicapai sekitar 200 - $500 \mathrm{~kg} / \mathrm{cm}^{2}$ namun tidak menutup kemungkinan bisa mencapai hingga lebih $1000 \mathrm{~kg} / \mathrm{cm}^{2}$.Kuat tekan beton dipengaruhi oleh jenis campuran, sifat agregat dan kualitan perawatan beton tersebut.

Berdasarkan SNI 1974:2011, kuat tekan beton dihitung dengan membagi beban maksimum yang diterima oleh beton benda uji selama pengujian dengan luas penampang melintang.

$$
f^{\prime} c=\frac{P}{A}
$$

dimana :

$\mathrm{f}^{\prime} \mathrm{c}=$ kuat tekan beton (Mpa)

$\mathrm{P}$ = gaya tekan aksial $(\mathrm{N})$

$\mathrm{A}=$ luas penampang melintang $\left(\mathrm{mm}^{2}\right)$

\section{METODE PELAKSANAAN}

Metode yang digunakan dalam pengujian ini ialah penelitian yang dilakukan dengan caramengadakan suatu percobaan untuk mendapatkan data atau hasil yang menghubungkan antara variabel-variabel atau yang disebut dengan penelitian eksperimental.

Dalam penelitian ini dilakukan percobaan dengan pembuatan benda uji beton dengan perbandingan 1:2:3 dengan fas 0,45. Benda uji beton dibentuk silinder dengan diameter $15 \mathrm{~cm}$ dan tinggi $30 \mathrm{~cm}$ dengan jumlah benda uji keseluruhan 48 buah benda uji yang terdiri dari 12 buah beton normal, 12 buah beton dengan campuran agregat cangkang kemiri 10\%, 12 buah beton dengan campuran agregat cangkang kemiri 20\% dan 12 buah beton dengan campuran agregat cangkang kemiri 30\%. Pengujian kuat tekan benda uji beton dilakukan pada umur beton 7, 14, 21 dan 28 hari.

\section{Alat dan Bahan}

Peralatan yang digunakan pada pengujian ini merupakan peralatan yang tersedia di Laboratorium Bahan, Universitas HKBP Nommensen Medan dan alat yang digunakan untuk melakukan pengujian kuat tekan dengan menggunakan alat Controls Milano - Italy.

Sedangkan bahan penyusun beton yang digunakan dalam penelitian ini adalah :

1. Semen portland type I

2. Agregat halus terdiri atas pasir sungai yang berasal dair sungai di Kota Binjai

3. Agregat kasar yaitu batu guli yang berasal dari Kota Binjai

4. Agregat kasar sebagian pengganti batu guli yaitu cangkang kemiri yang berasal dari Kabupaten Samosir

5. Air yang berasal dari Laboratorium Bahan, Universitas HKBP Nommensen Medan. 


\section{HASIL DAN PEMBAHASAN}

Hasil Pengujian Agregat

Dengan menggunakan nilai butiran maksimal $40 \mathrm{~mm}$ untuk batu guli dan 25 mm untuk butiran cangkang kemiri serta hasil pengujian pada agregat halus dapat dijabarkan seperti pada Tabel 2.berikut.

Tabel 2. Hasil pengujian agregat

\begin{tabular}{|c|c|c|c|}
\hline \multirow[b]{2}{*}{ Pengujian } & \multicolumn{2}{|c|}{ Agregat kasar } & \multirow[b]{2}{*}{$\begin{array}{c}\text { Agregat } \\
\text { halus }\end{array}$} \\
\hline & $\begin{array}{l}\text { Batu } \\
\text { guli }\end{array}$ & $\begin{array}{c}\text { Cangkang } \\
\text { kemiri }\end{array}$ & \\
\hline Berat jenis & 2,76 & 1,33 & 2,60 \\
\hline $\begin{array}{l}\text { Berat isi } \\
\left(\mathrm{gr} / \mathrm{cm}^{3}\right)\end{array}$ & 1,658 & 0,774 & 1,46 \\
\hline $\begin{array}{l}\text { Penyerapan } \\
\text { air (\%) }\end{array}$ & 1,77 & 8,65 & 1,79 \\
\hline $\begin{array}{l}\text { Kadar air } \\
(\%)\end{array}$ & 3,3 & 7,4 & 3,5 \\
\hline $\begin{array}{l}\text { Fine } \\
\text { modulus }\end{array}$ & 6,946 & 6,46 & 2,698 \\
\hline $\begin{array}{l}\text { Keausan } \\
(\%)\end{array}$ & 11,75 & 44,65 & - \\
\hline Zat organik & - & - & $\begin{array}{c}\text { standar } \\
\text { warna } \\
\text { (kuning } \\
\text { tua) }\end{array}$ \\
\hline
\end{tabular}

Sumber : hasil penelitian (2021)

Berdasarkan hasil pengujian agregat yang telah dilakukan terhadap batu guli dan cangkang kemiri ditemukan beberapa hal, antara lain :

1. Cangkang kemiri memiliki nilai persentase keausan lebih tinggi dibandingkan dengan batu guli

2. Berat jenis batu guli lebih tinggi bandingkan dengan berat jenis cangkang kemiri artinya bahwa batu guli memiliki daya serap air lebih rendah dibandingkan cangkang kemiri

3. Persentase penyerapan air cangkang kemiri lebih tinggi dibandingkan penyerapan air batu guli

\section{Komposisi Campuran Beton}

Dengan menggunakan berat isi beton normal $2400 \mathrm{~kg} / \mathrm{m}^{3}$ dan perbandingan antara kebutuhan material penyusun adalah 1:2:3 dan fas 0,45 maka, komposisi campuran beton yang digunakan dalam penyusunan benda uji pada penelitian ini dapat dilihat pada Tabel 3. berikut.
Tabel 3. Komposisi campuran beton per

$\mathbf{m}^{3}$

\begin{tabular}{|l|c|}
\hline \multirow{2}{*}{ Material penyusun } & $\begin{array}{c}\text { Kebutuhan } \\
\text { dasar beton }\end{array}$ \\
\cline { 3 - 3 } & $\left(\mathrm{kg} / \mathrm{m}^{3}\right)$ \\
\hline 1. Berat isi beton normal & 2400 \\
\hline 2. Semen & 372,10 \\
\hline 3. Agregat kasar & 1116,28 \\
\hline 4. Agregat halus & 744,18 \\
\hline 5. Air & 167,44 \\
\hline
\end{tabular}

Sumber : hasil penelitian (2021)

Sedangkan untuk komposisi campuran pada masing - masing kelompok benda uji dijabarkan pada Tabel 4.

\section{Hasil Pengujian Slump}

Dengan menggunakan Kerucut Abrams yang memiliki ukuran dimensi tinggi $30 \mathrm{~cm}$, diameter bawah $20 \mathrm{~cm}$ dan diameter atas $10 \mathrm{~cm}$ kemudian dilengkai dengan tongkat perojok diameter $16 \mathrm{~mm}$ dan panjang $60 \mathrm{~cm}$ maka didapatkan hasil pengujian slump pada setiap sampel benda uji seperti yang dijabarkan pada Tabel 5 berikut.

Tabel 5. Hasil pengujian slump

\begin{tabular}{|cc|c|}
\hline \multicolumn{2}{|c|}{ Material penyusun } & $\begin{array}{c}\text { Nilai } \\
\text { slump }\end{array}$ \\
\cline { 3 - 3 } & & (cm) \\
\hline 1. & Beton Normal $(\mathrm{BN})$ & 11 \\
\hline 2. & BN + cangkang kemiri 10 \% & 10,3 \\
\hline 3. & BN + cangkang kemiri $20 \%$ & 9,5 \\
\hline 4. & BN + cangkang kemiri 30 \% & 9 \\
\hline
\end{tabular}

Sumber : hasil penelitian (2021)

Berdasarkan Tabel 5 di atas didapatkan nilai hasil pengujian slump terhadap benda uji beton normal, beton normal dengan tambahan cangkang kemiri 10\%,20\% dan $30 \%$. Dapat diketahui bahwa beton normal memiliki nilai slump lebih tinggi dibandingkan dengan benda uji yang diberikan tambahan cangkang kemiri.

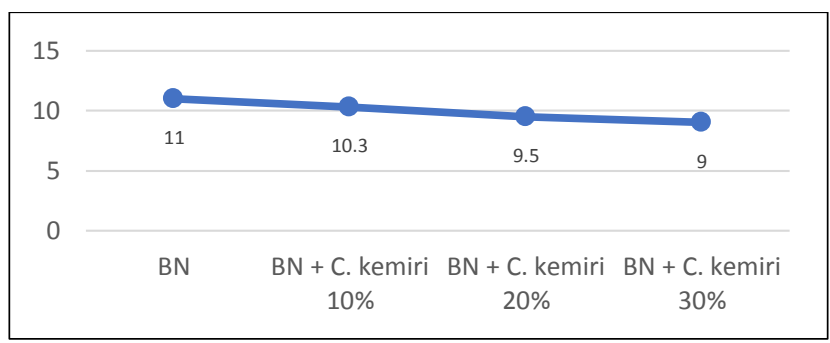

Gambar 1. Grafik nilai pengujian slump Sumber : hasil penelitian (2021) 
Tabel 4. Komposisi campuran beton untuk setiap kelompok sampel benda uji

\begin{tabular}{|c|c|c|c|c|c|}
\hline \multirow[b]{2}{*}{ No. } & \multirow[b]{2}{*}{$\begin{array}{c}\text { Material } \\
\text { penyusun } \\
\text { campuran }\end{array}$} & \multicolumn{4}{|c|}{ Jenis sampel benda uji } \\
\hline & & $\begin{array}{c}\text { Beton } \\
\text { Normal (BN) } \\
(\mathrm{kg})\end{array}$ & $\begin{array}{c}\mathrm{BN}+\text { cangkang } \\
\text { kemiri } 10 \% \\
(\mathrm{~kg})\end{array}$ & $\begin{array}{c}\text { BN + cangkang } \\
\text { kemiri 20\% } \\
(\mathrm{kg})\end{array}$ & $\begin{array}{c}\mathrm{BN}+\text { cangkang } \\
\text { kemiri } 30 \% \\
(\mathrm{~kg})\end{array}$ \\
\hline 1. & Semen & 23,66 & 24,84 & 24,84 & 24,84 \\
\hline 2. & Batu guli & 70,99 & 67,07 & 59,63 & 52,18 \\
\hline 3. & Pasir & 47,33 & 49,69 & 49,69 & 49,69 \\
\hline 4. & $\begin{array}{l}\text { Cangkang } \\
\text { kemiri }\end{array}$ & - & 7,453 & 14,90 & 22,35 \\
\hline 5. & Air & 10,64 & 11,17 & 11,17 & 11,17 \\
\hline
\end{tabular}

\section{Hasil Pengujian Kuat Tekan}

Pengujian kuat tekan beton dilakukan pada benda uji beton dengan umur 7, 14, 21 dan 28 hari dengan variasi penambahan cangkang kemiri 10\%, 20\%, 30\% dan beton normal. Hasil pengujian kuat tekan beton untuk beton normal dan beton dengan tambahan cangkang kemiri dijabarkan pada Tabel 6.

Berdasarkan data hasil pengujian pada Tabel 6 dan Gambar 2 ditemukan bahwa nilai kuat tekan beton maksimum pada beton normal umur 28 hari dengan nilai kuat tekan beton rata-rata yaitu $16.52 \mathrm{MPa}$. Sedangkan terhadap variasi beton dengan campuran cangkang kemiri, nilai kuat tekan beton maksimum ditemukan pada beton dengan variasi cangkang kemiri 10\% umur 28 hari yaitu 12,39 MPa. Nilai kuat tekan minimum ditemukan pada beton dengan campuran cangkang kemiri 30\% umur 7 hari yaitu sebesar 7,65 MPa.

Tabel 6. Hasil pengujian kuat tekan beton

\begin{tabular}{|c|c|c|c|c|c|c|c|c|c|}
\hline \multirow{3}{*}{\multicolumn{2}{|c|}{ Benda Uji }} & & & \multicolumn{6}{|c|}{ Kuat Tekan Beton (MPa) } \\
\hline & & $\mathrm{f}^{\prime} \mathrm{c}$ & fcr & $\mathrm{f}^{\prime} \mathrm{c}$ & fcr & $\mathrm{f}^{\prime} \mathrm{c}$ & fcr & $\mathrm{f}^{\prime} \mathrm{c}$ & fcr \\
\hline & & \multicolumn{2}{|c|}{7 hari } & \multicolumn{2}{|c|}{14 hari } & \multicolumn{2}{|c|}{21 hari } & \multicolumn{2}{|c|}{28 hari } \\
\hline \multirow{3}{*}{$\begin{array}{l}\text { 1. Beton Normal } \\
\text { (BN) }\end{array}$} & 1 & 10,11 & \multirow{3}{*}{10,25} & 12,08 & \multirow{3}{*}{11,71} & 14,16 & \multirow{3}{*}{14,30} & 16,56 & \multirow{3}{*}{16,52} \\
\hline & 2 & 10,36 & & 11,30 & & 14,46 & & 15,72 & \\
\hline & 3 & 10,28 & & 11,75 & & 14,28 & & 17,30 & \\
\hline \multirow{3}{*}{$\begin{array}{l}\text { 2. BN + Cang. Kemiri } \\
10 \%\end{array}$} & 1 & 9,33 & \multirow{3}{*}{9,30} & 9,96 & \multirow{3}{*}{10,43} & 11,01 & \multirow{3}{*}{11,08} & 12,44 & \multirow{3}{*}{12,39} \\
\hline & 2 & 9,85 & & 10,28 & & 11,19 & & 12,44 & \\
\hline & 3 & 8,73 & & 11,05 & & 10,83 & & 12,3 & \\
\hline \multirow{3}{*}{$\begin{array}{l}\text { 3. BN + Cang. Kemiri } \\
20 \%\end{array}$} & 1 & 8,99 & \multirow{3}{*}{8,82} & 9,06 & \multirow{3}{*}{9,33} & 9,94 & \multirow{3}{*}{10,15} & 9,72 & \multirow{3}{*}{10,49} \\
\hline & 2 & 9,42 & & 9,31 & & 10,11 & & 11,30 & \\
\hline & 3 & 8,05 & & 9,63 & & 10,41 & & 10,46 & \\
\hline \multirow{3}{*}{$\begin{array}{l}\text { 4. BN + Cang. Kemiri } \\
30 \%\end{array}$} & 1 & 7,71 & \multirow{3}{*}{7,65} & 8,99 & \multirow{3}{*}{8,28} & 8,92 & \multirow{3}{*}{8,92} & 10,40 & \multirow{3}{*}{9,87} \\
\hline & 2 & 7,71 & & 7,96 & & 9,52 & & 9,89 & \\
\hline & 3 & 7,53 & & 7,90 & & 8,33 & & 9,33 & \\
\hline
\end{tabular}

Sumber : hasil penelitian (2021) 


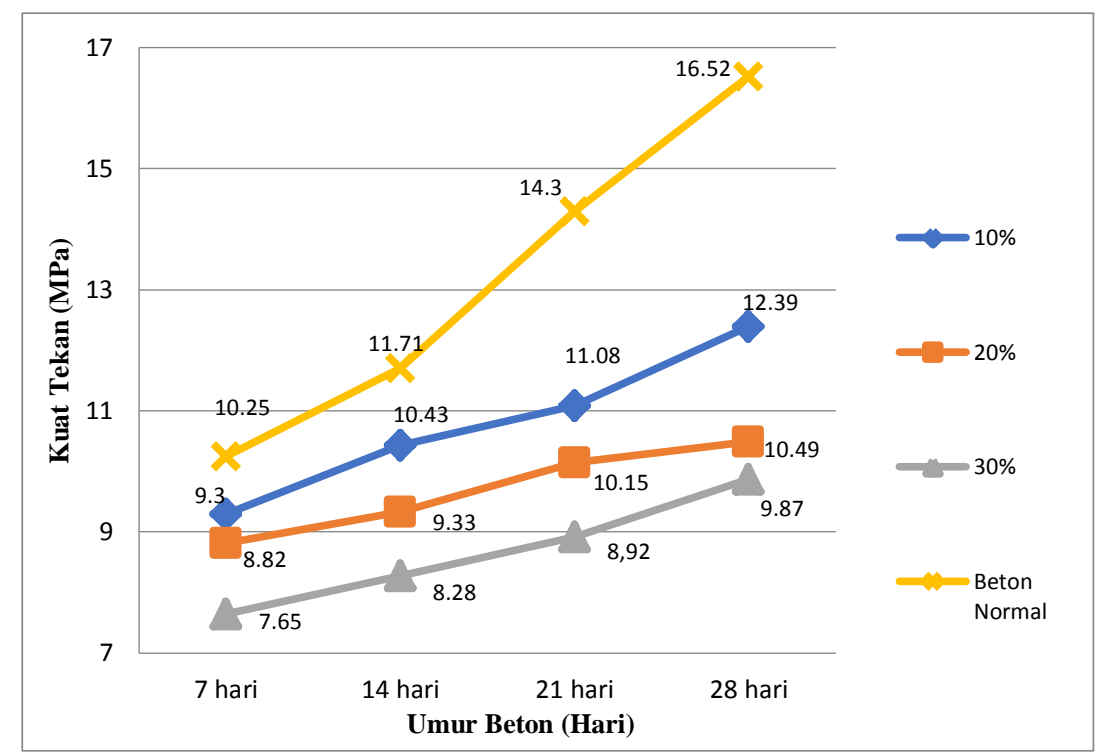

Gambar 2. Grafik perbandingan kuat tekan beton terhadap umur beton

Sumber : hasil penelitian (2011)

\section{SIMPULAN}

Berdasarkan pengujian yang telah dilakukan pada didapatkan kesimpulan sebagai berikut :

1. Berdasarkan pengujian slump pada semua kelompok benda uji ditemukan bahwa beton dengan penambahan cangkang kemiri sebagai pengganti sebagian agregat kasar memiliki tingkat workabilitas yang lebih rendah dibandingkan dengan beton normal tanpa tambahan cangkang kemiri.

2. Semakin besar persentase penambahan campuran cangkang kemiri, maka semakin rendah nilai slump-nya. Hal ini ditunjukkan dari ketiga jenis variasi beton dengan tambahan cangkang kemiri, nilai slump minimum ada pada beton dengan penambahan cangkang kemiri 30\% yaitu sebesar $9 \mathrm{~cm}$.

3. Pada pengujian kuat tekan beton didapatkan bahwa penambahan cangkang kemiri akan menghasilkan beton dengan kuat tekan yang rendah. Pada beton dengan penambahan cangkang kemiri $30 \%$ baik pada beton dengan umur 7 hari, 14 hari, 21 hari ataupun 28 hari menunjukkan bahwa nilai kuat tekannya menjadi lebih rendah dibandingkan dengan beton uji yang ditambahkan cangkang kemiri $10 \%$ dan $20 \%$.

\section{DAFTAR PUSTAKA}

Badan Pengembangan Sumber Daya Manusia Kemen PUPR. 2017. Modul 2 Diklat Perkerasan Kaku. Bandung

Badan Pusat Statistik. 2019. Konstruksi Dalam Angka 2019. Jakarta

Badan Standarisasi Nasional, 2004.Semen Portland. (SNI 15-2049-2004). Jakarta

Badan Standarisasi Nasional, 2002. Tata Cara Perhitungan Beton Untuk Bangunan Gedung. (SNI 03-2847-2002). Jakarta

Badan Standarisasi Nasional, 2011.Cara Uji Kuat Tekan Beton dengan Benda Uji Silinder.(SNI 1974:2011). Jakarta

Departemen Pekerjaan Umum dan Tenaga Listrik.1971. Peraturan Beton Bertulang Indonesia. Bandung

Departemen Pekerjaan Umum. 2005. Pelaksanaan Pekerjaan Beton Untuk Jalan dan Jembatan.Pedoman Konstruksi dan Bangunan Pd T-07-2005-B. Jakarta.

Dinas Perkebunan Provinsi Sumatera Utara. 2021. Data Luas Areal, Produksi dan Produktivitas Perkebunan Rakyat Komoditas Kemiri. http://disbun.sumutprov.go.id/statistik/ web/index.php? $r=$ site $\% 2$ Fgrafik\&tahun= 2019\&komoditas=11 (Diakses pada 9 Maret 2021 15.39 WIB)

Kardiyono Tjokrodimulyo. 1992. Teknologi Beton. UGM. Yogyakarta

Lincolen, K. 2017. Pengaruh Abu Terbang Sebagai Bahan Pengganti Semen Pada 
Beton Beragregat Halus Bottom Ash. Universitas Lampung. Lampung

Nugraha, P. 2007. Teknologi Beton dari Material Pembuatan ke Beton Kinerja Tinggi.Universitas Kristen Indonesia. Andi Offset. Yogyakarta

Oberlyn, J. S., Elita, T. S., Lumbangaol, P., Petrus S. P. 2020. Beton Bermutu Dan Ramah Lingkungan Dengan Memanfaatkan Limbah Abu Cangkang Sawit. Jurnal Darma Agung. (3)28, 387401.

Pusat Standarisasi Lingkungan dan Kehutanan. 2021. Teknologi Ramah Lingkungan.

http://standardisasi.menlhk.go.id/index. php/barangjasateknologi-ramahlingkungan/teknologi-ramah-lingkungan (Diakses pada 26 Februari 202110.18 WIB) 